\title{
Poverty, income inequality, and energy consumption based on EKC hypothesis: Evidence from developed and developing countries
}

Yusuf Ekrem Akbas ( $\square$ akbasyea@gmail.com )

Adıyaman Üniversitesi: Adiyaman Universitesi

Fuat Lebe

Osmaniye Korkut Ata Universitesi

\section{Research Article}

Keywords: Poverty, Income inequality, CO2 emissions, Fourier panel data analysis, Dynamic SUR.

Posted Date: March 18th, 2021

DOl: https://doi.org/10.21203/rs.3.rs-288310/v1

License: (c) (1) This work is licensed under a Creative Commons Attribution 4.0 International License.

Read Full License 


\title{
Poverty, income inequality, and energy consumption based on EKC hypothesis: Evidence from developed and developing countries
}

\author{
Yusuf Ekrem Akbaş ${ }^{1}$ and Fuat Lebe ${ }^{2}$
}

\begin{abstract}
The primary objective of this study is to examine the relationship between carbon dioxide $\left(\mathrm{CO}_{2}\right)$ emissions, energy consumption, income inequality, and poverty within the framework of the Environmental Kuznets Curve (EKC) in 14 developed and ten developing countries over the period 2000-2018. We employed the Fourier unit root test and Dynamic Seemingly Unrelated Regression (DSUR) estimator to analyze the relationship between these variables. The results show that in developing countries, income inequality, poverty, and energy consumption positively affect $\mathrm{CO}_{2}$ emission. In contrast, in developed countries, there is no significant relationship between these variables. Moreover, we found out that the EKC hypothesis, which suggests an inverted U-shaped relationship between per capita income and $\mathrm{CO}_{2}$ emissions, is valid in developed countries and invalid in developing countries. We determined that the turning points obtained from regression analysis are outside of the sample period in five developing countries (Argentina, Armenia, Kazakhstan, Panama, and Uruguay). These results show that income inequality and poverty can indirectly affect environmental quality by energy consumption in developing countries.
\end{abstract}

Keywords: Poverty, Income inequality, $\mathrm{CO}_{2}$ emissions, Fourier panel data analysis, Dynamic SUR.

JEL Classifications: Q43, C23, I30

${ }^{1}$ Corresponding Author: Yusuf Ekrem Akbaş, Faculty of Economics and Administrative Sciences, Department of Economics, Adıyaman University, 02040, Adıyaman/Turkey, email: akbasyea@gmail.com, yeakbas@adiyaman.edu.tr

${ }^{2}$ Fuat Lebe, Faculty of Economics and Administrative Sciences, Department of Economics, Osmaniye Korkut Ata University, 80000, Osmaniye/Turkey, email: fuatlebe@gmail.com, fuatlebe@ osmaniye.edu.tr 


\section{Introduction}

Identifying the sources of economic growth and the nature of the economic development and environment nexus is a complicated issue. Technological change-oriented growth does not cause climate changes such as ecological deterioration and air pollution, while growth due to increased use of resources may cause climate changes (Sarkodie,2018). These effects and interactions bring to mind the Environmental Kuznets Curve (EKC) hypothesis. This hypothesis cannot be ignored while investigating the relationship between pollution and national income (Mahmood et al.,2020).

Although Kuznets developed the EKC in 1955, the idea of EKC became popular with the study of Grossman and Krueger's (1991). According to this hypothesis, while the economic development activities cause the environmental conditions to deteriorate, economic growth also includes the solution to environmental degradation (Kuznets,1955). The EKC expresses that economic growth causes a disruptive effect on the environment; however, after a certain point of income level, the disruptive impact to the environment caused by the economic growth starts to decrease due to the rise in the country's income (Ahmed et al., 2017). This quadratic effect is known as the EKC hypothesis (Grossman and Krueger, 1991). The EKC hypothesis presumes that the environmental degradation and income nexus is inverted-U shaped, not linear (Kusumawardani and Dewi, 2020).

Economic growth is an essential component of environmental degradation (Bimonte, 2002). But the other variables such as income distribution, poverty, education may play an essential role in determining environmental quality. Baek and Gweisah (2013) expressed that early researhes in the EKC literature did not reflect reality since only GDP per capita was used to clarify environmental degradation in these studies. Thus, early studies ignoring variables that are essential determinants of ecological problems may be biased (Iwata et al., 2010). Last studies indicate that some variables such as energy consumption (Ahmed et al.,2017; Muhammad, 2019), financial development (Charfeddine and Khediri, 2016; Pata, 2018), foreign direct investments (Shahbaz et al., 2019; Mahmood et al., 2020), trade openness (Lebe, 2016), and the urbanization (Al-Mulali et al., 2015; McGee and Greiner, 2018) can explain the environmental pollution. Therefore, the EKC hypothesis has been tested for a long time focusing on $\mathrm{CO}_{2}$ emissions and different other variables, such as foreign direct investment, energy consumption, financial development, trade openness, industrialization, export, import, labor, capital, urbanization, and globalization. Researchers have been using similar variables in addition to per capita income and environmental degradation to remove the problem of ignored variables. Thus, poverty and income distribution which have essential social and economic effects, are usually not used as a determinant in EKC studies and have been ignored (Torras and Boyce, 1998; Baek and Gweisah, 2013; Morse, 2018). Thereby, as income distribution and poverty are not attached to studies, possible relationships between income distribution, poverty, and environmental degradation cannot be exposed (Wolde-Rufael and Idowu, 2017; Grunewald et al., 2017).

The problem of income inequality and poverty is economical for developing countries and also constitutes social and political issues. Governments tend to focus on poverty alleviation and income inequality-reducing policies instead of macroeconomic issues such as economic growth and employment in countries with high-income inequality and poverty. Therefore, policymakers cannot implement enough strategies to increase personal income. In these countries, social problems such as a low level of culture and education, insufficiency of health services, and inadequate environmental consciousness development are usually encountered. Thus, it is expected that individuals in countries where income inequality and poverty high polluted the environment more compare to individuals in countries with low-income inequality and poverty. This result causes higher $\mathrm{CO}_{2}$ emissions in countries with high poverty and income inequality than countries with low-poverty and income inequality, as the EKC hypothesis suggests. According to the EKC hypothesis, with economic development, production, and industrial activities increase. Thus, environmental pollution increases along with economic growth in the first phase of development (Onafowora and Owoye, 2014). On the other hand, economic growth does not increase environmental pollution in the advanced stage of development. As mentioned above, the personal income level, level of education, and culture have improved in this phase. Moreover, the use of high-tech and environmentfriendly technology has increased. For these reasons, $\mathrm{CO}_{2}$ emissions decrease in these countries.

At the early stages of countries' development, where poverty is still pervasive, there is low environmental awareness, ineffective tax collection, and much funding cannot be allocated for environmental protection (Panayotou, 1993). EKC hypothesis expresses that this stage is the initial stage. At the first stages of economic development, multidimensional poverty is high. Therefore, environmental conservation policies are usually neglected in initial stage of economic growth. On the other hand, in the later stages of growth, there is a significant increase in income levels along with awareness of environmental sustainability, sufficient institutional quality, innovation, and diffusion of technology which contributes a decrease in environmental degradation (Sarkodie and Strezov, 2019).

Environmental degradation, poverty, and income inequality are some of the critical global issues that wait to resolve. However, the interactions of these variables in the literature of ecological economics have not been adequately analyzed. In the literature, studies have generally focused on the income inequality and environmental degradation nexus. Our study conceptualizes poverty and income inequality as an indicator of environmental degradation. We use the EKC hypothesis to test the GDP, poverty, and income inequality nexus in developing and 
developed countries. Thus, it is expected that this study connects the three directions of sustainable growth, including the social, economic, and environmental aspects, and fills in the research gap observed in the $\mathrm{CO}_{2}$ emissions, poverty, and inequality, poverty nexus.

We have tested the EKC hypothesis in 24 countries (10 developing and 14 developed countries) between 2000-2018. We have applied Dynamic SUR estimator. As control variables, we used energy consumption, poverty, and income inequality. This study has probably three main contributions. This study contributes to the literature in three-way i) Although the earlier studies investigate the EKC linkage between income per capita and energy consumption, almost no studies explore this relationship for income poverty and inequality (Hassan et al., 2015). Given the importance of environmental degradation, it is crucial to fill this gap. ii) In this study, we used the Fourier panel unit root test and dynamic SUR test, unlike conventional econometric methods in the literature. These tests make the study different from the other studies in the literature as these tests take into consideration the structural shifts and cross-section dependence between observed countries. Neglecting the structural changes and the cross-section dependence between cross-section units may lead to bias results. iii) Finally, to test the validity of EKC by including poverty and income inequality variables in our analyzes, a large population of countries was formed, including developed and developing countries. This paper can provide developing countries information about how developed countries reach their current economic conditions. Also, such studies can help policymakers in implementing a suitable and effective policy to control environmental degradation and support sustainable growth and development.

This study is organized as follows: In the second part, there is literature about the EKC hypothesis focusing on income inequality and poverty nexus. In the third part, the data and the methods used in the study can be found. In the fourth part, there are empirical findings, and in the last part, there is a section for the results and policy recommendations.

\section{Literature review}

In this section, we will review the literature on income inequality and macroeconomic variables nexus based on the Kuznets curve theory. Then, we will focus on the relationships between poverty, income inequality, and the EKC hypothesis, in line with our purpose.

The studies of Holtz-Eakin and Selden (1995), Grossman and Krueger (1995), and Cole et al. (1997) are accepted as the pioneer studies to confirm the EKC hypothesis. These studies stated that environmental pollution increases with income level in the early stages and declines when income level exceeds a certain level. Since that time, it is seen that empirical studies on EKC have intensified, especially in $2017^{1}$ and beyond.

The role of income inequality for socio-economic developments has been extensively considered in the literature. In some of these studies, the relationship between income inequality and macroeconomic variables such as financial development, economic growth, export diversification, and such has been examined, and findings that confirm the EKC hypothesis have been obtained (Campano and Salvatore,1988; Nielsen and Alderson,1997; Paweenawat and McNown,2014; Meniago and Asongu,2018; Le et al.,2020). In some empirical studies, conclusions that do not support the EKC hypothesis have been obtained. (Papanek and Kyn,1986; List and Gallet,1999; Galor and Moav,2004; Perera and Lee,2013; Yang and Greaney,2017).

As previously expressed, empirical studies focus on to designate environmental degradation, income inequality, and poverty nexus. All of these studies only researched the relationship between ecological degradation \& income inequality or poverty \& ecological degradation in the analysis (Magnani,2000; Baek and Gweisah,2013; Ali et al.,2016; Hao et al.,2016; Grunewald et al.,2017; Knight et al., 2017; Jorgenson et al.,2017; McGee and Greiner,2018; Khan et al.,2018; Liu et al.,2019; Uzar and Eyuboglu,2019; Kusumawardani and Dewi,2020). Poverty has been neglected in these analyses. For example, Magnani (2000) analyzed the effects of income inequality on $\mathrm{CO}_{2}$ emissions in OECD countries between 1980-1991. He concluded that there was a U-shaped relation between $\mathrm{CO}_{2}$ emissions and economic growth. Also, he found that income equality decreased $\mathrm{CO}_{2}$ emissions. Baek and Gweisah (2013) researched the effects of income inequality on $\mathrm{CO}_{2}$ emissions using the Autoregressive Distributed Lag Model (ARDL) approach. They concluded that there was an equal income distribution in better environmental quality. Hao et al. (2016) investigated the impacts of income inequality on $\mathrm{CO}_{2}$ emissions using the Generalized Method of Moments technique between 1995-2012 in China. Findings indicated that $\mathrm{CO}_{2}$ emissions increase as income inequality rises. Also, there was a U-shaped relation between economic growth and $\mathrm{CO}_{2}$ emissions. Ali et al. (2016) analyzed the impact of income inequality on the $\mathrm{CO} 2$ emissions of Africa using the panel ARDL method. They concluded that the impact of income inequality on $\mathrm{CO}_{2}$ emissions was negative, and increasing income inequality could reduce $\mathrm{CO}_{2}$ emissions. Grunewald et al. (2017) researched the $\mathrm{CO}_{2}$ emissions and income inequality nexus in 158 countries between 1980-2008. They found that the impact of income inequality on $\mathrm{CO}_{2}$ emissions was negative. Besides, they found that the relationship depends on the level of income. Accordingly, the authors determined that higher income inequality caused lower carbon emissions in low and middle-income economies; in return for this, they found the income inequality increased per

\footnotetext{
${ }^{1}$ See the study of Sarkodie, S.A., Strezov, V. (2019) for detailed literature about the EKC hypothesis.
} 
capita emissions in upper-middle-income and high-income economies. Also, the empirical results confirm the EKC hypothesis. Knight et al. (2017) investigated carbon dioxide emissions and domestic wealth inequality nexus in 26 high-income countries between 2000-2010. They concluded that income inequality is significantly and positively effect on $\mathrm{CO}_{2}$ emissions in high-income countries. Jorgenson et al. (2017) investigated the linkage between income inequality measures (the income share of the top $10 \%$ and the Gini coefficient) and $\mathrm{CO}_{2}$ emissions in the US. However, the EKC hypothesis was not tested in this study. Findings show that income inequality positively affects the $\mathrm{CO}_{2}$ emissions. On the other hand, the authors concluded that the effect of Gini coefficient on carbon dioxide emissions is insignificant. McGee and Greiner (2018) investigated how income distribution affects the linkage between $\mathrm{CO}_{2}$ emissions and economic growth in the 38 most developed nations between 19852011. They determined that increasing income inequality involves to a tighter coupling between $\mathrm{CO}_{2}$ emissions and economic growth in developed countries. Also, no evidence to confirm the traditional EKC hypothesis could not be found in this study. Khan et al. (2018) examined the impacts of income inequality on carbon dioxide emissions for the three developing Asian countries over 1980-2014. The results reveal that income inequality decreases the $\mathrm{CO}_{2}$ emission in Pakistan and India, while the result in Bangladesh is the opposite. Also, the results of the analysis confirm the validity EKC hypothesis' validity in Pakistan and India. Liu et al. (2019) examined how the income distribution within 30 Chinese provinces affected the $\mathrm{CO}_{2}$ emissions of these province between 1996-2014. The authors found that income inequality enhanced $\mathrm{CO}_{2}$ emissions and this result confirms the EKC hypothesis. Uzar and Eyuboglu (2019) examined the impact of income distribution on Turkey's $\mathrm{CO}_{2}$ emissions during 1984-2014 using ARDL. The authors found that income inequality positively affects $\mathrm{CO}_{2}$ emissions, and the Gini coefficient is the Granger-cause of $\mathrm{CO}_{2}$ emission. They also concluded that the $\mathrm{EKC}$ is valid in Turkey. Kusumawardani and Dewi (2020) tested the effect of income inequality on Indonesia's $\mathrm{CO}_{2}$ emissions between 1975-2017. They used the ARDL method for analysis and determined that income inequality negatively affects $\mathrm{CO}_{2}$ emissions. Consequently, they confirmed the validity of the EKC hypothesis. These studies' common feature in the literature is to test the environmental degradation and income inequality nexus in the countries and regions considered.

Although there are lots of study about $\mathrm{CO}_{2}$ emissions and income inequality, few studies are dealing with the relationship between environmental degradation and poverty (Zaman et al.,2011; Rizk and Ben Slimane,2018; Koçak et al.,2019; Khan,2019; Baloch et al., 2020; Dhrifi et al.,2020). For instance, Zaman et al. (2011) investigated the relationship between environment degradation and poverty in Pakistan from 1975 to 2009 using the ARDL method. The results show that air pollution caused poverty. Rizk and Ben Slimane (2018) researched the linkage between poverty and $\mathrm{CO}_{2}$ emission in 146 countries between 1996-2014. The authors found a negative linkage between $\mathrm{CO}_{2}$ emission and poverty for both low-high income countries and the overall sample, and an inverted N-shaped linkage was revealed between poverty and $\mathrm{CO}_{2}$ emissions. Koçak et al. (2019) analyzed the $\mathrm{CO}_{2}$ emissions and poverty nexus in the $48 \mathrm{Sub}$-Saharan African countries between 2010-2016. They used panel data methods. The results of analysis show that there is a strong linkage between poverty alleviation and $\mathrm{CO}_{2}$ emissions reduction efforts. Khan (2019) examined the role of poverty under environmental deterioration in ASEAN states between 2007-2017. The results show that there is a significant and positive linkage between environmental degradation and poverty. Findings indicate that an increase in income inequality and poverty cause rising $\mathrm{CO}_{2}$ emissions. However, the EKC hypothesis was not tested in the study. Baloch et al. (2020) researched the income inequality, poverty, and $\mathrm{CO}_{2}$ emissions nexus in 40 Sub-Saharan African countries for the period between 2010 and 2016. Dhrifi et al. (2020) tested the $\mathrm{CO}_{2}$ emission and poverty nexus in 98 developing countries between 1995-2017. As a result of the analysis, a bi-directional causal link between $\mathrm{CO}_{2}$ emission and poverty was determined. Besides, they found that poverty negatively affects $\mathrm{CO}_{2}$ emissions and confirms the EKC hypothesis's validity.

There is a lack of studies in the literature that address both poverty and income inequality within the EKC hypothesis framework. The EKC study, which includes poverty and inequality, is almost absent except for the study of Hassan et al. (2015). Hassan et al. (2015) investigated affecting $\mathrm{CO}_{2}$ emissions because of changes in poverty, inequality, and growth triangle in Pakistan between 1980-2011. The used cointegration approach for the analysis. The authors concluded that there was no significant linkage between poverty and $\mathrm{CO}_{2}$ emissions, while there was a negative linkage between $\mathrm{CO}_{2}$ emissions and income inequality. On the other side, they revealed that there was a positive linkage between poverty and income inequality. The results confirm the EKC hypothesis's validity.

\section{Data and Methodology}

\subsection{Data}

In this study, we used the Gini coefficient (GINI), poverty (POV), real gross domestic product per capita (GDP), carbon dioxide emissions $\left(\mathrm{CO}_{2}\right)$, and energy consumption (EC) for the analysis. The annual data covers the period from 2000 to 2018 for ten developing and 14 developed countries was used. The GINI coefficient, which measures the Lorenz curve's maximum area and an imaginary line representing perfect equality, is used to obtain income inequality measures. POV is the population ratio that lives on less than $\$ 3.20$ per day to the total 
population. GDP and its square represent the real GDP measured as US dollars in 2010 prices. EC is measured in billion-kilowatt hours. $\mathrm{CO}_{2}$ is used as per capita. Poverty, Gini coefficient, and real GDP per capita data were procured from World Development Indicators (WDI). The $\mathrm{CO}_{2}$ emissions and energy use data were procured from the Energy Information Administration (EIA). All variables were used in logarithmic form. We preferred data and countries according to their availability in the database.

\subsection{Theoretical model}

EKC hypothesis states that environmental degradation increases at the first stage of growth. Nevertheless, after reaching income at a certain level, the quality of the environment slowly starts to improve. The model that is the basis of the study is defined as follows:

$$
\mathrm{CO}_{2}=f\left(G D P, G D P^{2}, E C, P O V, G I N I\right)
$$

In Eq.(1), EC, POV, and GINI represent the control variables. Eq. (1) can be derived to establish the dynamic linkage between GDP per capita, energy consumption, poverty, income inequality, and $\mathrm{CO}_{2}$ emission is as follows:

$$
\ln C O_{2_{i t}}={ }_{0}+{ }_{1} \ln G D P_{i t}+{ }_{2} \ln G D P_{i t}^{2}+{ }_{3} \ln E C_{i t}+{ }_{4} \ln P O V_{i t}+{ }_{5} \ln G I N I_{i t}+{ }_{i t}
$$

Eq. (2) indicates the log-linear quadratic model applied in this study. $\mathrm{CO}_{2}$ determines the carbon dioxide emission per capita that is often used for environmental degradation. $G D P$ is real gross domestic product per capita that denotes the economic growth, $E C$ is energy consumption, $P O V$ is poverty, GINI is income inequality, and $\varepsilon_{i t}$ is an error term of the regression. The EKC hypothesis describes the $\alpha_{1}$ and $\alpha_{2}$ coefficients are negative and positive, respectively. The $\alpha_{3}, \alpha_{4}$, and $\alpha_{5}$ coefficients can be determined in this study. All variables in the analysis are used in a logarithmic form.

\subsection{Fourier Panel Unit Root Test}

We use the panel unit root test developed by Nazlioglu and Karul (2017), which takes into consideration gradual structural breaks and cross-sectional dependency in this study. This test also allows heterogeneity across cross-sectional units. It can capture the unknown nature of structural breaks without information about the number of breaks. This method's test procedure bases on the unit root test that structural changes are modeled with a Fourier approximation, developed by Becker et al. (2006). In this test, the cross-section dependency problem is also tackled with a common factor structure as in the panel unit root test developed by Hadri and Kurozumi $(2011,2012)$. The individual statistic and panel statistic have a Fourier frequency and a standard normal distribution, respectively. The null hypothesis of this test indicates the stationarity, while the alternative hypothesis shows the nonstationarity.

$$
\begin{aligned}
& y_{i t}=\alpha_{i}(t)+r_{i t}+\delta_{i} F_{t}+\varepsilon_{i t} \\
& r_{i t}=r_{i t-1}+u_{i t}
\end{aligned}
$$

Where $i=1, \ldots, N$ cross-section dimension, $t=1, \ldots . . T$ time dimension, $r_{i t}$ is random walk process. $\varepsilon_{i t}$ and $u_{i t}$ are mutually independent and identically distrubuted (i.i.d) across $\mathrm{i}$ and over $t$ with $E\left(\varepsilon_{i t}\right)=0$, $E\left(\varepsilon_{i t}^{2}\right)=\sigma_{\varepsilon i}^{2}>0, E\left(u_{i t}\right)=0, E\left(u_{i t}^{2}\right)=\sigma_{u i}^{2}>0$, a finite fourth-order moment. $F_{t}$ is unobserved common factor and serially uncorrelated with $E\left(F_{t}\right)=0$ and $\delta_{i}$ are the loading weights. $F_{t}$ is stationary and serially uncorrelated with $E\left(F_{t}\right)=0$ and $E\left(F_{t}^{2}\right)=\sigma_{F}^{2}>0 . \delta_{i}, \varepsilon_{i t}$, and $F_{t}$, and are separately distrubuted for all $i$. Also, it is presumed that $F_{t}$ is known.

The individual statistic allowing the Fourier is described as:

$$
\eta_{i}(k)=\frac{1}{T} \frac{\sum_{t=1}^{T} \mathcal{S}_{i t}{ }_{\delta}(k)^{2}}{\delta \tilde{g}_{i}}
$$


Where $\mathscr{S}_{i t}(k)=\sum_{j=1}^{t} \varepsilon_{i j}$ is the partial sum process by using the OLS residuals from Eq. (5), and $\mathcal{O}_{\varepsilon i}^{2}$

is estimation long-run variance of $\varepsilon_{i t}$. This stuation can be described as follows:

$$
\sigma_{\varepsilon i}^{2}=\lim _{T \rightarrow \infty} T^{-1} E\left(S_{i t}^{2}\right)
$$

The Fourier panel statistic $(\mathrm{FP}(k))$ is obtained by individual statistics' average. The $F P(k)$ can be calculated as follows:

$$
F P(k)=\frac{1}{N} \sum_{i=1}^{N} \eta_{i}(k)
$$

\subsection{Dynamic SUR}

Dynamic SUR estimator (DSUR) developed by Mark et al. (2005) takes into consideration the crosssectional dependence to estimate the model. Wald statistics, which have restrictive chi-square distributions, can be constituted to analyze cross-equation restrictions such as heterogeneity restrictions and homogeneity restrictions in the co-integration vectors. DSUR estimator can be implemented in two-steps. In the first step, the regression in each model is regressed on the leads and lags of the first difference of the regressors. Thus, endogeneity problem, which means that the explanatory variables and error term are correlated, can be controlled. The SUR strategy is applied to the residuals from the first step regressions in the second step. DSUR, which estimates the multiple cointegrating regressions, is a parametric method. This method is applicable for balanced panels in which the number of cointegrating regression equations $(\mathrm{N})$ is substantially smaller than the number of time-series observations (T). The method is feasible both in the heterogeneous panel and in the homogeneous panel. Also, the DSUR estimator considers the endogeneity (Mark et al., 2005).

\section{Empirical Findings}

\subsection{Results of Panel Fourier Unit Root Test}

We used $\mathrm{CD}_{\mathrm{LM}}$ tests of Breusch and Pagan (1980) and Pesaran et al. (2008) to analyze whether there is a cross-sectional dependency. According to Table A1, the null hypothesis expresses that no cross-section dependence for the variable is rejected both in developing and developed countries. After determining the crosssection dependence, we applied the FP unit root test.

The results in Tables 1 and 2 show that the null of stationary hypothesis is rejected at least at a $10 \%$ significance level for both frequencies in all developed and developing countries.

\begin{tabular}{|c|c|c|c|c|c|c|c|c|c|c|c|c|}
\hline \multirow[b]{2}{*}{ Country } & \multicolumn{2}{|c|}{$\mathrm{CO}_{2}$} & \multicolumn{2}{|c|}{ GDP } & \multicolumn{2}{|c|}{ GDP $^{2}$} & \multicolumn{2}{|c|}{ EC } & \multicolumn{2}{|c|}{ POV } & \multicolumn{2}{|c|}{ GINI } \\
\hline & $k=1$ & $k=2$ & $k=1$ & $\mathrm{k}=2$ & $k=1$ & $k=2$ & $k=1$ & $k=2$ & $k=1$ & $k=2$ & $k=1$ & $k=2$ \\
\hline Argentina & 0.18 & 0.17 & 0.40 & 0.10 & 0.09 & 0.09 & 0.72 & 0.26 & 0.57 & 0.62 & 0.33 & 0.27 \\
\hline Bulgaria & 0.87 & 0.17 & 1.08 & 0.25 & 1.08 & 0.25 & 2.76 & 0.11 & 0.29 & 0.07 & 0.09 & 0.06 \\
\hline Estonia & 0.08 & 0.12 & 0.08 & 0.22 & 0.08 & 0.22 & 0.06 & 0.20 & 0.14 & 0.08 & 0.12 & 0.11 \\
\hline Kazakhstan & 0.13 & 0.07 & 0.50 & 0.05 & 0.50 & 0.05 & 0.39 & 0.09 & 0.49 & 0.23 & 0.13 & 0.15 \\
\hline Panama & 0.06 & 0.12 & 0.53 & 0.22 & 0.53 & 0.22 & 0.66 & 0.60 & 0.35 & 0.04 & 0.31 & 0.25 \\
\hline Romania & 0.53 & 0.42 & 0.57 & 0.64 & 0.57 & 0.64 & 0.42 & 0.06 & 0.12 & 0.02 & 0.09 & 0.20 \\
\hline Armenia & 0.12 & 0.19 & 0.42 & 0.13 & 0.42 & 0.09 & 0.28 & 0.09 & 0.11 & 0.09 & 0.19 & 0.14 \\
\hline Bolivia & 0.30 & 0.28 & 0.09 & 0.66 & 0.09 & 0.68 & 0.18 & 0.21 & 0.06 & 0.09 & 0.09 & 0.05 \\
\hline CostaRica & 0.93 & 0.49 & 0.47 & 0.05 & 0.47 & 0.05 & 0.52 & 0.50 & 0.69 & 1.21 & 0.48 & 0.83 \\
\hline Uruguay & 0.33 & 0.04 & 0.09 & 0.19 & 0.09 & 0.19 & 0.13 & 0.08 & 1.68 & 0.25 & 0.04 & 0.06 \\
\hline Panel st. & 15.9 & 1.73 & 24.9 & 1.57 & 24.9 & 1.57 & 30.3 & 11.7 & 22.8 & 2.56 & 6.74 & 1.73 \\
\hline$p$-value & 0.00 & 0.08 & 0.00 & 0.06 & 0.00 & 0.06 & 0.00 & 0.00 & 0.00 & 0.00 & 0.00 & 0.04 \\
\hline
\end{tabular}

Table 1. The results of panel unit root test for developing country

Note: Bold numbers state that the null of stationary hypothesis is accepted at the 10 percent level of significance. The analysis was applied to constant model. The critical values of constant model for individual statistics are 0.2699 (1\%), $0.1720(5 \%)$, and $0.1318(10 \%)$ for $k=1 ; 0.6671(1 \%), 0.4152(5 \%)$, and $0.3150(10 \%)$, for $k=2$.

As a result of individual statistics, when the frequency is one, $\mathrm{CO}_{2}$ is stationary in five countries (Argentina, Estonia, Kazakhstan, Panama, Armenia). When the frequency is two, it is stationary in eight countries except for two countries (Romania, Costa Rica). GDP and GDP 2 are stationary in two of the ten countries (Bolivia, Uruguay) when the Fourier frequency is one. GDP and its square are stationary in eight countries except for Romania and Bolivia when the frequency is two. EC is stationary in three of ten countries (Estonia, Bolivia, 
Uruguay). When the Fourier frequency is two, except for two countries (Panama, Costa Rica), other countries are stationary. POV is stationary in four of ten countries (Estonia, Romania, Armenia, Bolivia) when the frequency is one. When the frequency is two, except for two countries (Argentina, Costa Rica), POV is stationary in eight countries. Finally, when the frequency is one, the GINI coefficient is found to be stationary in six countries (Estonia, Kazakhstan, Romania, Armenia, Bolivia, Uruguay). When the frequency is two, it is stationary in all of the countries except Costa Rika.

The results for developed countries show similarity with the results of developing countries. According to Table 2, the null hypothesis of stationarity is rejected for six variables in developed countries. The overall panel results differ from individual statistics of countries. According to individual statistics, when the Fourier frequency is one, $\mathrm{CO}_{2}$ is stationary in three countries (Denmark, Ireland, Netherlands); GDP and GDP ${ }^{2}$ are stationary in one country (Canada). Also, EC is stationary in four countries (Netherlands, Norway, Sweden, US). Furthermore, POV is stationary in five countries (Austria, Ireland, Netherlands, Sweden, Switzerland); and GINI is stationary in six countries (Denmark, Finland, Germany, Ireland, Norway, Switzerland). When the Fourier frequency is two, we found that the number of variables determined as stationary increased. When the frequency is two, CO2 is stationary in eleven countries except for three countries (Canada, Finland, Italy). Furthermore, GDP and its square are stationary in one country (Japan); EC is stationary in six countries (Austria, France, Italy, Netherlands, Sweden, US). Also, POV is stationary in three countries (Canada, France, Switzerland); and GINI is stationary in six countries (Austria, Finland, France, Germany, Italy, Japan, Netherlands, Switzerland).

282

Table 2. The results of panel unit root test for developed country

\begin{tabular}{|c|c|c|c|c|c|c|c|c|c|c|c|c|}
\hline \multirow[b]{2}{*}{ Country } & \multicolumn{2}{|c|}{$\mathrm{CO}_{2}$} & \multicolumn{2}{|c|}{$G D P$} & \multicolumn{2}{|c|}{$G D P^{2}$} & \multicolumn{2}{|c|}{$E C$} & \multicolumn{2}{|c|}{ POV } & \multicolumn{2}{|c|}{ GINI } \\
\hline & $k=1$ & $k=2$ & $k=1$ & $k=2$ & $k=1$ & $k=2$ & $k=1$ & $k=2$ & $k=1$ & $k=2$ & $k=1$ & $k=2$ \\
\hline Austria & 0.31 & 0.07 & 1.50 & 0.65 & 1.50 & 0.65 & 0.26 & 0.16 & 0.08 & 0.35 & 0.41 & 0.17 \\
\hline Canada & 0.34 & 1.35 & 0.17 & 0.51 & 0.16 & 0.51 & 0.13 & 0.83 & 0.72 & 0.16 & 0.35 & 0.52 \\
\hline Denmark & 0.08 & 0.29 & 0.57 & 0.68 & 0.57 & 0.68 & 0.25 & 0.49 & 0.61 & 0.38 & 0.15 & 0.27 \\
\hline Finland & 0.48 & 0.44 & 0.61 & 0.89 & 0.61 & 0.89 & 0.19 & 0.49 & 0.35 & 0.69 & 0.18 & 0.16 \\
\hline France & 1.38 & 0.09 & 0.47 & 9.85 & 0.47 & 9.85 & 0.13 & 0.16 & 0.42 & 0.26 & 0.68 & 0.24 \\
\hline Germany & 0.19 & 0.24 & 0.66 & 0.80 & 0.66 & 0.80 & 0.12 & 0.21 & 0.40 & 0.48 & 0.05 & 0.15 \\
\hline Ireland & 0.19 & 0.28 & 0.92 & 2.65 & 0.92 & 2.65 & 0.20 & 0.21 & 0.17 & 0.35 & 0.07 & 1.45 \\
\hline Italy & 0.40 & 0.48 & 0.76 & 2.14 & 0.75 & 2.14 & 0.77 & 0.17 & 0.28 & 0.31 & 0.51 & 0.27 \\
\hline Japan & 0.25 & 0.25 & 0.37 & 0.40 & 0.37 & 0.40 & 0.54 & 0.42 & 0.29 & 0.80 & 0.29 & 0.29 \\
\hline Netherlands & 0.14 & 0.14 & 0.24 & 1.42 & 0.24 & 1.42 & 0.06 & 0.29 & 0.19 & 0.43 & 0.25 & 0.25 \\
\hline Norway & 0.32 & 0.26 & 2.09 & 5.46 & 2.09 & 5.46 & 0.09 & 0.32 & 0.56 & 0.33 & 0.06 & 0.30 \\
\hline Sweden & 0.35 & 0.31 & 0.21 & 0.69 & 0.21 & 0.69 & 0.08 & 0.11 & 0.18 & 0.36 & 1.14 & 0.35 \\
\hline Switzerland & 0.64 & 0.21 & 0.78 & 1.16 & 0.78 & 1.16 & 0.66 & 0.43 & 0.19 & 0.14 & 0.06 & 0.21 \\
\hline US & 0.62 & 0.30 & 0.23 & 0.98 & 0.23 & 0.98 & 0.17 & 0.20 & 0.40 & 0.81 & 0.53 & 0.50 \\
\hline Panel st. & 23.7 & 5.58 & 43.2 & 53.1 & 43.2 & 53.1 & 13.7 & 5.07 & 18.6 & 7.82 & 18.2 & 6.10 \\
\hline$p$-value & 0.00 & 0.00 & 0.00 & 0.00 & 0.00 & 0.00 & 0.00 & 0.00 & 0.00 & 0.00 & 0.00 & 0.00 \\
\hline
\end{tabular}

Note: Bold numbers state that the null of stationary hypothesis is accepted at least at the 10 percent level of significance. The critical values of constant model for individual statistics are $0.2699(1 \%), 0.1720(5 \%)$, and $0.1318(10 \%)$ for $k=1 ; 0.6671(1 \%), 0.4152(5 \%)$, and $0.3150(10 \%)$ for $k=2 ; 0.7182(1 \%), 0.4480(5 \%)$, and $0.3393(10 \%)$ for $k=3$.

The results of panel statistics indicate that all of the series include unit roots in both country groups. However, individual statistics differ between countries. In some countries, the series is stationary, while in others, they are non-stationary. But in most countries, when the Fourier frequency is one, it is determined that the series are non-stationary. These results indicate that $\mathrm{CO}_{2}$ emissions and energy consumption can be guided by the policies implemented by national and international organizations. Moreover, these results show that poverty and income inequality can be influenced by the policies implemented by policy authorities such as the government and the central bank.

\subsection{Results of dynamic SUR estimator}

According to Table 3, both GDP and GDP' are positive. This result shows that $\mathrm{CO}_{2}$ emissions increase when the income level rises in developing countries, so the EKC hypothesis is not valid in developing countries because the linkage between $\mathrm{CO}_{2}$ and GDP is not inverted U-shaped. Also, individual statistics show that the EKC hypothesis is not valid in any ten developing countries. Besides, a significant amount of the monetary values of turning points for these ten developing countries are outside our study sample period. The turning points obtained as \$11.556, \$14.234, \$25.754, \$20.974, \$7.348 for Argentina, Armenia, Kazakhstan, Panama, and Uruguay, respectively, are higher than per capita GDP, which occurred as \$10.404, \$4406, \$10.867, \$11.530, and \$14.437, 
respectively for these five countries. Therefore, environmental pollution continues increasing in Argentina, Armenia, Kazakhstan, Panama, and Uruguay because these countries have not yet reached these turning points. In the other five countries (Bulgaria, Estonia, Romania, Bolivia, Costa Rica), the turning points do not exceed to per capita GDP of these countries.

Moreover, there are positive relationships from POV, GINI, and $\mathrm{EC}$ to $\mathrm{CO}_{2}$ in developing countries. When individual statistics are evaluated, it is shown that POV is statistically significant and positive in Argentina, Bulgaria, Kazakhstan, Bolivia, and Uruguay in Table 3. Also, GINI is significant and positive in Argentina, Bulgaria, Bolivia, and Costa Rica. Finally, EC is significant and positive in Argentina, Bulgaria, Estonia, Romania, and Uruguay.

Table 3. The results of dynamic SUR estimator for developing countries

\begin{tabular}{|c|c|c|c|c|c|c|c|c|c|c|c|}
\hline \multirow[b]{2}{*}{ Country } & \multicolumn{2}{|c|}{ GDP } & \multicolumn{2}{|c|}{$G D P^{2}$} & \multicolumn{2}{|c|}{ POV } & \multicolumn{2}{|c|}{ GINI } & \multicolumn{2}{|c|}{$E C$} & \multirow{2}{*}{$\begin{array}{l}\text { Turning } \\
\operatorname{point}(\$)\end{array}$} \\
\hline & Coeff. & $t$-st. & Coeff. & $t$-st. & Coeff. & $t$-st. & Coeff. & $t$-st. & Coeff & $t$-st. & \\
\hline Argentina & 0.28 & $7.27^{\text {**** }}$ & 0.142 & $7.275^{\text {*** }}$ & 0.12 & $1.901^{*}$ & 0.25 & $3.14^{* * * *}$ & 0.14 & $3.65^{* * *}$ & 11.556 \\
\hline Bulgaria & 0.11 & $2.408^{* * *}$ & -0.01 & -0.494 & 0.58 & $3.54^{* * * *}$ & 0.35 & $3.81^{\text {**** }}$ & 0.45 & $4.32^{* * * *}$ & 3.697 \\
\hline Estonia & 0.16 & 1.721 & 0.077 & $3.340^{* * *}$ & 0.32 & 0.910 & 0.89 & 0.587 & 0.24 & $3.94^{* * *}$ & 11.482 \\
\hline Kazakhstan & 0.30 & $12.2^{* * *}$ & 0.153 & $16.08^{* * *}$ & 0.26 & $2.541^{* *}$ & 0.49 & 1.347 & 0.57 & 0.946 & 25.754 \\
\hline Panama & 0.93 & $3.62^{* * *}$ & 0.488 & $3.315^{* * *}$ & 0.37 & 0.914 & -0.35 & -1.245 & 0.12 & 1.087 & 20.974 \\
\hline Romania & -0.09 & -0.876 & -0.08 & $-1.976^{*}$ & 0.57 & 1.341 & 0.89 & 1.027 & 0.35 & $2.94^{* *}$ & 2.006 \\
\hline Armenia & 0.36 & $4.46^{* * *}$ & 0.160 & $6.585^{* * *}$ & 0.15 & 1.241 & -0.18 & -0.987 & 0.87 & 1.247 & 14.234 \\
\hline Bolivia & 0.46 & $9.71^{* * *}$ & 0.240 & $11.00^{* * * *}$ & 0.16 & $1.924^{*}$ & 0.48 & $2.647^{* *}$ & 0.58 & 1.431 & 6.083 \\
\hline CostaRica & 0.11 & $4.08^{* * * *}$ & 0.073 & $3.188^{* * * *}$ & 0.28 & 1.024 & 0.24 & $2.452^{* *}$ & 0.57 & 1.242 & 8.627 \\
\hline Uruguay & 0.09 & 1.282 & 0.049 & 1.282 & 0.12 & $1.912^{*}$ & 0.25 & 1.575 & 0.31 & $2.65^{* *}$ & 7.348 \\
\hline Panel stat. & 0.28 & $6.01^{* * *}$ & 0.144 & $6.012^{* * * *}$ & 0.30 & $1.903^{*}$ & 0.49 & $2.914^{* *}$ & 0.31 & $4.64^{* * *}$ & - \\
\hline
\end{tabular}

The invalidity of the EKC hypothesis in developing countries can be related to the development level. Although development includes economic growth, it is a much comprehensive term than economic growth. The development is the advancement of a country in economic, social, cultural, technological, and political issues. In developing countries, economic growth is insufficient. Moreover, developing countries are at a lower level than the developed countries in terms of education level and using environmental-friendly technology. Therefore, it is expected that in developing countries, carbon dioxide emissions also rise due to the low environmental consciousness, insufficient use of environmental-friendly technologies, and low education levels.

The positive relationship in Table 3 between poverty, income inequality, energy consumption, and $\mathrm{CO}_{2}$ emission also can be related to income level. In developing countries, per capita income is low. Therefore, in developing countries, individuals cannot be expected to sufficiently consider environmental pollution to meet their needs, such as warming and shelter. Also, in developing countries, technology use that does not harm the environment is inadequate compared to developed countries since this technology is costly. For these reasons, $\mathrm{CO}_{2}$ emissions are expected to rise as poverty rises in developing countries. This result shows a similarity with that energy consumption affects $\mathrm{CO}_{2}$ positively. In addition to the low-income level and inadequate use of environmentally friendly technology, the development of environmental awareness in individuals cannot be expected to be high enough due to financial difficulties in developing countries (Selden and Song,1994).

The results indicating the $\mathrm{CO}_{2}$ and GDP nexus in developed countries are shown in Table 4. Accordingly, GDP and GDP ${ }^{2}$ are statistically significant. The GDP and the GDP ${ }^{2}$ coefficients are positive and negative, respectively. Thus, the linkage between $\mathrm{CO}_{2}$ and GDP is an inverted U-shaped. Therefore, the EKC hypothesis is valid in developed countries. However, the individual statistics confirm the EKC hypothesis in nine countries. However, these statistics do not support the EKC hypothesis in the other five countries (Austria, France, Italy, Japan, Switzerland). Also, turning points are smaller than GDP per capita in fourteen countries. 
Table 4. The results of dynamic SUR estimator for developed countries

\begin{tabular}{|c|c|c|c|c|c|c|c|c|c|c|c|}
\hline \multirow[b]{2}{*}{ Country } & \multicolumn{2}{|c|}{$G D P$} & \multicolumn{2}{|c|}{$G D P^{2}$} & \multicolumn{2}{|c|}{ POV } & \multicolumn{2}{|c|}{ GINI } & \multicolumn{2}{|c|}{$E C$} & \multirow{2}{*}{$\begin{array}{l}\text { Turning } \\
\text { point }(\$)\end{array}$} \\
\hline & Coeff. & $t$-st. & Coeff. & $t$-st. & Coeff. & $t$-st. & Coeff. & $t$-st. & Coeff. & $t$-st. & \\
\hline Austria & 0.04 & 1.813 & -0.02 & -1.81 & -0.12 & -1.03 & 0.58 & $2.510^{* * *}$ & 0.78 & 1.024 & 39.749 \\
\hline Canada & 0.09 & $3.29^{* * *}$ & -0.04 & $-3.2^{* * * *}$ & -0.2 & -0.98 & 0.12 & 1.102 & 0.68 & 1.241 & 30.798 \\
\hline Denmark & 0.30 & $2.588^{* *}$ & -0.15 & $-2.5^{* *}$ & 0.09 & 1.035 & 0.25 & 0.974 & 0.05 & 0.982 & 40.336 \\
\hline Finland & 0.18 & 1.812 & -0.09 & $-1.81^{*}$ & -0.23 & $-2.1^{* *}$ & 0.14 & 0.894 & 0.03 & 1.067 & 36.495 \\
\hline France & 0.12 & -1.494 & -0.06 & -1.49 & -0.41 & -1.01 & 0.06 & $1.901^{*}$ & 0.07 & 0.913 & 24.215 \\
\hline Germany & 0.08 & $4.89^{* * *}$ & -0.04 & $-4.8^{* * * *}$ & -0.24 & -1.10 & 0.24 & 0.845 & 0.16 & 0.879 & 38.430 \\
\hline Ireland & 0.14 & $2.726^{* *}$ & -0.07 & $-2.7^{* * *}$ & 0.77 & 0.891 & 0.57 & 0.946 & 0.36 & 0.917 & 41.778 \\
\hline Italy & 0.12 & -1.272 & -0.06 & -1.272 & -0.47 & -1.24 & 0.07 & $1.867^{*}$ & 0.53 & 1.071 & 34.305 \\
\hline Japan & 0.22 & 1.160 & 0.11 & 1.160 & 0.1 & 0.990 & 0.79 & 1.024 & 0.19 & 0.876 & 41.780 \\
\hline Netherlands & 0.02 & $2.013^{*}$ & -0.01 & $-2.01^{*}$ & 0.89 & 1.050 & 0.36 & 1.149 & 0.24 & 1.310 & 39.051 \\
\hline Norway & 0.13 & $3.864^{* * * *}$ & -0.06 & $-3.8^{* * *}$ & -0.54 & -0.97 & -0.19 & -1.024 & 0.73 & 1.254 & 73.165 \\
\hline Sweden & 0.10 & $4.832^{* * * *}$ & -0.05 & $-4.8^{* * * *}$ & 0.35 & 1.178 & 0.37 & 0.974 & 0.46 & 0.893 & 14.212 \\
\hline Switzerland & 0.07 & -1.182 & -0.03 & -1.18 & 0.36 & 1.120 & -0.19 & -1.049 & 0.23 & 0.901 & 46.634 \\
\hline US & 0.07 & $3.462^{* * * *}$ & -0.03 & $-3.4^{* * * *}$ & -0.12 & -0.98 & 0.64 & 0.879 & 0.46 & 1.167 & 34.065 \\
\hline Panel stat. & 0.089 & $4.694^{* * *}$ & -0.04 & $-4.7^{\text {**** }}$ & -0.01 & -1.25 & 0.650 & 0.950 & 0.524 & 0.780 & - \\
\hline
\end{tabular}

Note: ${ }^{*, * *}$ and ${ }^{* * *}$ show the significance at 10,5 and $1 \%$ levels, respectively.

Finally, it is determined that there are insignificant relationships from POV, GINI, and EC to $\mathrm{CO}_{2}$. This result may be caused by low-income inequality and low level of poverty in developed countries. The fact that there is no relationship between income inequality, poverty, energy consumption, and $\mathrm{CO}_{2}$ may originate from a too low level of poverty and inequality in developed countries. The fact that poverty and income inequality are too small to affect other variables in developed countries may cause the causality relationship between these two variables to become insignificant. Moreover, in developed countries, individuals have high environmental awareness and use environmentally friendly technology. High environmental awareness and environmentally friendly technology do not much-increase carbon monoxide emissions, even if it increases energy consumption. This situation may cause the effect of energy consumption on $\mathrm{CO}_{2}$ to be insignificant.

\section{Conclusion}

This study analyzed the EKC hypothesis for the period between 2000-2018 in developing and developed countries. Furthermore, whether there was a relationship between poverty, income inequality, energy use, personal income, and carbon dioxide was analyzed in the study. For this purpose, the FP unit root test and the DSUR estimator were used.

As a result of the FP unit root test, it was found that all variables in both developing and developed countries contain unit-roots. These results show that when a shock occurs in GDP, energy consumption, $\mathrm{CO}_{2}$, poverty, and income inequality, the equilibrium cannot be achieved itself and therefore requires external intervention. Thus, these variables can be influenced by policies implemented by policymakers in both developing and developed countries. Policymakers in developing countries can achieve their targets by implementing procedures to increase income levels and reduce inequality and poverty. Policymakers in developed countries can also be successful in their policies to decrease $\mathrm{CO}_{2}$ emissions.

The results of DSUR estimator show that the EKC hypothesis is not valid in developing countries since $\mathrm{CO}_{2}$ and GDP nexus is not inverted U-shaped. These results are consistent with Rizk and Ben Slimane's (2018) results and Dhrifi et al. (2020). Besides, it was determined that energy consumption, income inequality, and poverty positively affect $\mathrm{CO}_{2}$ emissions in developing countries. These results support the studies conducted by Hao et al. (2016), Ali et al. (2016), Khan et al. (2018, Liu et al. (2019), Uzar and Eyuboglu (2019), Khan (2019), and Baloch et al. (2020). While there is a positive relationship between GDP and $\mathrm{CO}_{2}$ emissions in developing countries, there is an inverted $\mathrm{U}$-shaped relationship between GDP and $\mathrm{CO}_{2}$ emissions in developed countries. Also, it is found that the effects of income inequality, energy consumption, and poverty on $\mathrm{CO}_{2}$ emissions are insignificant in developed countries. These results support the results of Jorgenson et al. (2017).

Since there is no inverted U-shaped relationship between GDP and $\mathrm{CO}_{2}$ in developing countries, analysed in this study, the policy implementations to increase the economic growth may not harm the environment and 
increase the $\mathrm{CO}_{2}$ emissions. Moreover, as industrialization in these countries is at a low level, an increase in economic growth is not expected to be big enough to affect the ecological system negatively. Therefore, in developing countries, policy authorities should first implement economic growth and development policies rather than implementing procedures to protect environmental regulations and environmental systems. Furthermore, it was determined that turning points are higher than the income level in five developing countries analyzed in this study (Argentina, Armenia, Kazakhstan, Panama, and Uruguay). Therefore, policymakers should firstly concentrate on increasing the income level in these four countries. Then, they should try to achieve environmentally friendly development. In developing countries, poverty and income inequality are also high. The relationship between energy consumption, poverty, income inequality, and $\mathrm{CO}_{2}$ can be explained by income level. People with low income are direct emitters of $\mathrm{CO}_{2}$ since they use the direct natural resources intensively, take low remedial measures about the environment, and have low education levels. For these reasons, educational institutions and non-governmental organizations in developing countries should raise awareness about the importance of natural resources and educate individuals about natural resources. In developing countries, poverty and income inequality are high when compared to developed countries. In developing countries, policy authorities can make infrastructure investments such as health, education, transportation, and communication to reduce poverty and income inequality. These investments may contribute to the employment of the population with low income and the reduction of income inequality. Thus, governmental policies should target to solve the problem of poverty and income inequality. In this context, a low-income population can be provided with basic primary education and agricultural education. In this way, people with low income can be employed, and the basic income level of population with low income can be increased. Consequently, income inequality and poverty should be decreased to obtain sustainable and environmentally friendly development in developing countries.

The fact that the EKC hypothesis' validity and poverty, income inequality, and energy consumption are not effective on $\mathrm{CO}_{2}$ in developed countries shows that energy conservation policies, such as controlling carbon dioxide emissions and rationing energy consumption, will not negatively affect the real output growth. Therefore, policy authorities should implement policies to reduce $\mathrm{CO}_{2}$ emissions in developed countries. Moreover, using renewable energy sources rather than fossil fuel in the manufacturing industry, the transportation sector, and heating systems can be encouraged to reduce $\mathrm{CO}_{2}$ emissions. Besides, in 2018, the turning points of all developed countries are higher than the income levels. 
Authors' contributions Yusuf Ekrem Akbaş: Conceived and designed the experiments, performed the experiments, contributed reagents, materials, analysis tools or data, wrote the paper; Fuat Lebe: Wrote introduction and literature review; analyzed and interpreted the data.

Availability of data and materials The datasets generated and/or analyzed during the current study are mainly from 2000 to 2018 "World Development Indicators" and the "Energy Information Administration."

Ethics approval Note applicable.

Consent to participate Note applicable.

Consent for publication Note applicable.

Conflict of interests The authors declare no conflict of interest.

Competing interests The authors declare that they have no known competing financial interests or personel relationships that could have appeared to influence the work in this paper.

Funding This research did not receive any specific grant from funding agencies in the public, commercial, or not-for-profit sectors.

Acknowledgements Note applicable. 
Ahmed, K., Rehman, M.U., Ozturk, I. (2017). What drives carbon dioxide emissions in the long-run? Evidence from selected South Asian countries. Renew. Sustain. Energy Rev. 70, 11421153.https://doi.org/10.1016/j.rser.2016.12.018

Ali, H.S., Hassan, S., Kofarmata, Y.I. (2016). Dynamic impact of income inequality on carbon dioxide emissions in Africa: New evidence from heterogeneous panel data analysis. Int. J. Energy Econ. Pol. 6(4), 760766.https://ideas.repec.org/a/eco/journ2/2016-04-12.html

Al-Mulali, U., Weng-Wai, C., Shaeu-Ting, L., Mohammed, A.H. (2015). Investigating the environmental kuznets curve hypothesis by utilizing the ecological footprint as an indicator of environmental degradation. Ecol. Indic. 48, 315-323.https://doi.org/10.1016/j.ecolind.2014.08.029

Baek, J., Gweisah, G. (2013). Does income inequality harm the environment? Empirical evidence from the United States. Energy Policy 62, 1434-1437.https://doi.org/10.1016/j.enpol.2013.07.097

Baloch, M.A., Danish, Khan, A.U-D., Şentürk Ulucak, Z., Ahmas, A. (2020). Analyzing the relationship between poverty, income inequality, and $\mathrm{CO}_{2}$ emission in Sub-Saharan African countries. Sci. Total Environ. 740, 139867.https://doi.org/10.1016/j.scitotenv.2020.139867

Becker, R., Enders, W., Lee, J. (2006). A stationarity test in the presence of an unknown umber of smooth breaks. J. Time Ser. Anal. 27(3), 381-409.

Bimonte, S. (2002). Information access, income distribution, and the Environmental Kuznets Curve. Ecol. Econ. 41(1), 145-156.https://doi.org/10.1016/S0921-8009(02)00022-8

Breusch, T.S., Pagan, A.R. (1980). The Lagrange multiplier test and its applications to model specification tests in econometrics. Rev. Econ. Stud. 47(1), 239-53.https://doi.org/10.2307/2297111

Campano, F., Salvatore, D. (1988). Economic development, income inequality and Kuznets'U-shaped hypothesis. J. Policy Modell. 10(2), 265-280.https://doi.org/10.1016/0161-8938(88)90005-1

Charfeddine, L., Khediri, K.B. (2016). Financial development and environmental quality in UAE: Cointegration with structural breaks. Renew. Sustain. Energy Rev. 55, 13221335.https://doi.org/10.1016/j.rser.2015.07.059

Cole, M.A., Raymer, A.J., Bates, J.M. (1997). The environmental Kuznets curve: An empirical analysis. Environ. Dev. Econ. 2(4), 401-416.https://doi.org/10.1017/S1355770X97000211

Dhrifi, A., Jaziri, R., Alnahdi, S. (2020). Does foreign direct investment and environmental degradation matter for poverty? Evidence from developing countries. Struct. Change Econ. Dynam. 52, 1321.https://doi.org/10.1016/j.strueco.2019.09.008

Galor, O., Moav, O. (2004). From physical to human capital accumulation: Inequality and the process of development. Rev. Econ. Stud. 71(4), 1001-1026.https://doi.org/10.1111/0034-6527.00312

Grossman, G.M., Krueger, A.B. (1991). Environmental impacts of a North American free trade agreement. NBER Working Papers Series No. 3914. Cambridge, National Bureau of Economic Research.

Grossman, G.M., Krueger, A.B. (1995). Economic growth and the environment. Q. J. Econ. 110(2), 353377.https://doi.org/10.2307/2118443

Grunewald, N., Klasen, S., Martinez-Zarzoso, I. Muris, C. (2017). The trade-off between income inequality and carbon dioxide emissions. Ecol. Econ. 142, 240-256.https://doi.org/10.1016/j.ecolecon.2017.06.034

Hadri, K., Kurozumi, E. (2011). A locally optimal test for no unit root in cross-sectionally dependent panel data. Hitotsubashi J. Econ. 52(2), 165-184.https://econpapers.repec.org/RePEc:qub:wpaper:1102

Hadri, K., Kurozumi, E. (2012). A simple panel stationarity test in the presence of serial correlation and a common factor. Econ. Lett. 115, 31-34.https://doi.org/10.1016/j.econlet.2011.11.036

Hao, Y., Chen, H., Zhang, Q. (2016). Will income inequality affect environmental quality? Analysis based on China's provincial panel data. Ecol. Indic. 67, 533-542. https://doi.org/10.1016/j.ecolind.2016.03.025

Hassan, S.A., Zaman, K., Gul, S. (2015). The Relationship between growth-inequality-poverty triangle and environmental degradation: Unveiling the reality. Arab Econ. Bus. J. 10, 5771.https://doi.org/10.1016/j.aebj.2014.05.007

Holtz-Eakin, D., Selden, T.M. (1995). Stoking the fires? $\mathrm{CO}_{2}$ emissions and economic growth. J. Public Econ. 51(1), 85-101.https://doi.org/10.1016/0047-2727(94)01449-X

Iwata, H., Okada, K., Samreth, S. (2010). Empirical study on the environmental Kuznets curve for $\mathrm{CO}_{2}$ in France: the role of nuclear energy. Energy Policy 38(8), 4057-4063.https://doi.org/10.1016/j.enpol.2010.03.031

Jorgenson, A., Schor, J., Huang, X. (2017). Income inequality and carbon emissions in the United States: a statelevel analysis, 1997-2012. Ecol. Econ. 134, 40-48.https://doi.org/10.1016/j.ecolecon.2016.12.016 
Khan, A.Q., Saleem, N., Fatima, S.T. (2018). Financial development, income inequality, and $\mathrm{CO}_{2}$ emissions in Asian countries using STIRPAT model. Environ. Sci. Pollut. Res. 25, 63086319.https://doi.org/10.1007/s11356-017-0719-2

Khan, S.A.R (2019). The nexus between carbon emissions, poverty, economic growth, and logistics operationsempirical evidence from Southeast Asian countries. Environ. Sci. Pollut. Res. 26(13), 13210-13220.

Knight, K.W., Schor, J.B., Jorgenson, A.K. (2017). Wealth inequality and carbon emissions in high-income countries. Soc. Cur. 4, 403-412.https://doi.org/10.1177/2329496517704872

Koçak, E., Ulucak, R., Dedeoğlu, M., Ulucak, Z.Ş. (2019). Is there a trade-off between sustainable society targets in Sub-Saharan Africa? Sustain. Cit. Soc. 51, 101705.https://doi.org/10.1016/j.scs.2019.101705

Kusumawardani, D., Dewi, A.K. (2020). The effect of income inequality on carbon dioxide emissions: a case study of Indonesia. Heliyon 6(8), e04772.https://doi.org/10.1016/j.heliyon.2020.e04772

Kuznets, S. 1955. Economic growth and income inequality. Am. Econ. Rev. 45(1), 1-28.

Le, T-H., Nguyen, C.P., Su, T.D., Tran-Nam, B. (2020). The Kuznets curve for export diversification and income inequality: Evidence from a global sample. Econ. Anal. Policy 65, 2139.https://doi.org/10.1016/j.eap.2019.11.004

Lebe, F. (2016). The Environmental Kuznets Curve hypothesis: Cointegration and causality analysis for Turkey. Doğuş Univ. J. 17(2), 177-194.

List, J.A., Gallet, C.A. (1999). The Kuznets curve: What happens after the inverted-U? Rev. Dev. Econ. 3(2), 200206.https://econpapers.repec.org/RePEc:bla:rdevec:v:3:y:1999:i:2:p:200-206

Liu, Q., Wang, S., Zhang, W., Li, J., Kong, Y. (2019). Examining the effects of income inequality on $\mathrm{CO}_{2}$ emissions: Evidence from non-spatial and spatial perspectives. Appl. Energy 236, 163171.https://doi.org/10.1016/j.apenergy.2018.11.082

Magnani, E. (2000). The environmental Kuznets curve, environmental protection policy and income distribution. Ecol. Econ. 32(3), 431-443.https://doi.org/10.1016/S0921-8009(99)00115-9

Mahmood, H., Alkhateeb, T.T.Y., Furqan, M. (2020). Exports, imports, foreign direct investment and $\mathrm{CO}_{2}$ emissions in North Africa: Spatial analysis. Energy Rep. 6, 24032409.https://doi.org/10.1016/j.egyr.2020.08.038

Mark, N.C., Ogaki, M., Sul, D. (2005). Dynamic seemingly unrelated cointegrating regressions. Rev. Econ. Stud. 72(3), 797-820.https://doi.org/10.1111/j.1467-937X.2005.00352.x

McGee, J.A., Greiner, P.T. (2018). Can reducing income inequality decouple economic growth from $\mathrm{CO}_{2}$ emissions? Socius 4, 1-11.https://doi.org/10.1177/2378023118772716

Meniago, C., Asongu, S.A. (2018). Revisiting the finance-inequality nexus in a panel of African countries. Res. Int. Bus. Finance 46, 399-419.https://doi.org/10.1016/j.ribaf.2018.04.012

Morse, S. (2018). Relating environmental performance of nation states to income and income inequality. Sustain. Dev. 26, 99-115.https://doi.org/10.1002/sd.1693

Muhammad, B. (2019). Energy consumption, $\mathrm{CO}_{2}$ emissions and economic growth in developed, emerging and Middle East and North African countries. Energy 179, 232245.https://doi.org/10.1016/j.energy.2019.03.126

Nazlioglu, S., Karul, C. (2017). A panel stationarity test with gradual structural shifts: Re-investigate the international commodity price shocks. Econ. Modell. 61, 181192.https://doi.org/10.1016/j.econmod.2016.12.00

Nielsen, F., Alderson, A.S. (1997). The Kuznets Curve and the Great U-Turn: Income inequality in U.S. counties, 1970 to 1990. Am. Sociol. Rev. 62(1), 12-33.https://doi.org/10.1086/341329

Onafowora, O.A., Owoye, O. (2014). Bounds Testing Approach to Analysis of the Environment Kuznets Curve Hypothesis. Energy Econ. 44, 47-62.https://doi.org/10.1016/j.eneco.2014.03.025

Panayotou, T. (1993). Empirical tests and policy analysis of environmental degradation at different stages of economic development. ILO Working Papers 238, Geneva. https://econpapers.repec.org/RePEc:ilo:ilowps:992927783402676

Papanek, G.F., Kyn, O. (1986). The effect on income distribution of development, the growth rate and economic strategy. J. Dev. Econ. 23(1), 55-56.https://doi.org/10.1016/0304-3878(86)90079-9

Pata, U.K. (2018). Renewable energy consumption, urbanization, financial development, income and $\mathrm{CO}_{2}$ emissions in Turkey: Testing EKC hypothesis with structural breaks. J. Clean. Prod. 187, 770779.https://doi.org/10.1016/j.jclepro.2018.03.236 
Paweenawat, S.W., McNown, R. (2014). The determinants of income inequality in Thailand: A synthetic cohort analysis. J. Asian Econ. 31-32, 10-21.https://doi.org/10.1016/j.asieco.2014.02.001

Pesaran, H.M., Ullah, A., Yamagata, T. (2008). A bias-adjusted LM test of error cross-section independence. Econom. J. 11(1), 105-127.https://doi.org/10.1111/j.1368-423X.2007.00227.x

Perera, L.D.H., Lee, G.H.Y. (2013). Have economic growth and institutional quality contributed to poverty and inequality reduction in Asia? J. Asian Econ. 27, 71-86.https://doi.org/10.1016/j.asieco.2013.06.002

Rizk, R., Ben Slimane, M. (2018). Modelling the relationship between poverty, environment, and institutions: a panel data study. Environ. Sci. Pollut. Res. 25, 31459-31473.https://doi.org/10.1007/s11356-018-3051-6

Sarkodie, A.S. (2018). The invisible hand and EKC hypothesis: what are the drivers of environmental degradation and pollution in Africa? Environ. Sci. Pollut. Res. 25, 21993-22022.https://doi.org/10.1007/s11356-018$\underline{2347-\mathrm{X}}$

Sarkodie, S.A., Strezov, V. (2019). A review on Environmental Kuznets Curve hypothesis using bibliometric and meta-analysis. Sci. Total Environ. 649, 128-145.https://doi.org/10.1016/j.scitotenv.2018.08.276

Shahbaz, M., Lorente, D., Sinha A. (2019). Foreign direct investment- $\mathrm{CO}_{2}$ emissions nexus in Middle East and North African countries: Importance of biomass energy Consumption. J. Clean. Prod. 217, 603614.https://doi.org/10.1016/j.jclepro.2019.01.282

Torras, M., Boyce, J.K. (1998). Income, inequality, and pollution: A reassessment of the environmental Kuznets Curve. Ecol. Econ. 25(2), 147-160.https://doi.org/10.1016/S0921-8009(97)00177-8

Uzar, U., Eyuboglu, K. (2019). The nexus between income inequality and $\mathrm{CO}_{2}$ emissions in Turkey. J. Clean. Prod. 227, 149-157.https://doi.org/10.1016/j.jclepro.2019.04.169

Wolde-Rufael, Y., Idowu, S. (2017). Income distribution and $\mathrm{CO}_{2}$ emission: A comparative analysis for China and India. Renew. Sustain. Energy Rev. 74, 1336-1345.https://doi.org/10.1016/j.rser.2016.11.149

Yang, Y., Greaney, T.M. (2017). Economic growth and income inequality in the Asia-Pacific region: A comparative study of China, Japan, South Korea, and the United States. J. Asian Econ. 47, 622.https://doi.org/10.1016/j.asieco.2016.10.008

Zaman, K., Shah, I.A., Khan., M.M., Ahmad, M. (2011). Exploring the link between poverty-pollution-population (3Ps) in Pakistan: Time series evidence. J. Econ. Sustain. Dev. 2(11-12), 1-27. 
Table A1. The Results of Cross Section Dependence Test for Variables

\begin{tabular}{|c|c|c|c|c|}
\hline & \multicolumn{2}{|c|}{$C D_{L M}$} & \multicolumn{2}{|c|}{ CDLMadj } \\
\hline & Statistic & $p$-value & Statistic & $p$-value \\
\hline Variables & \multicolumn{4}{|c|}{ Developing Countries } \\
\hline $\mathrm{CO}_{2}$ & $6.3254^{* * *}$ & 0.0000 & $7.88794^{* * *}$ & 0.0000 \\
\hline$G D P$ & $5.2165^{* * *}$ & 0.0000 & $6.98455^{* * *}$ & 0.0000 \\
\hline$G D P^{2}$ & $5.2165^{* * *}$ & 0.0000 & $9.48722^{* * *}$ & 0.0000 \\
\hline$E C$ & $8.5145^{* * *}$ & 0.0000 & $9.98787^{* * *}$ & 0.0000 \\
\hline POV & $8.9879^{* * *}$ & 0.0000 & $5.15425^{* * *}$ & 0.0000 \\
\hline \multirow[t]{2}{*}{ GINI } & $10.024^{* * *}$ & 0.0000 & $8.21545^{* * *}$ & 0.0000 \\
\hline & \multicolumn{4}{|c|}{ Developed Countries } \\
\hline $\mathrm{CO}_{2}$ & $6.3254^{* * * *}$ & 0.0000 & $7.88794^{* * * *}$ & 0.0000 \\
\hline$G D P$ & $5.2165^{* * *}$ & 0.0000 & $6.98455^{* * *}$ & 0.0000 \\
\hline$G D P^{2}$ & $5.2165^{* * *}$ & 0.0000 & $9.48722^{* * *}$ & 0.0000 \\
\hline$E C$ & $8.5145^{* * *}$ & 0.0000 & $9.98787^{* * *}$ & 0.0000 \\
\hline POV & $8.9879^{* * *}$ & 0.0000 & $5.15425^{* * *}$ & 0.0000 \\
\hline GINI & $10.024^{* * *}$ & 0.0000 & $8.21545^{* * *}$ & 0.0000 \\
\hline
\end{tabular}




\section{Supplementary Files}

This is a list of supplementary files associated with this preprint. Click to download.

- Supplementarymaterial.docx 